\title{
EXPLORING A LAW FIRM BUSINESS MODEL TO IMPROVE ACCESS TO JUSTICE
}

\author{
Andrew Pilliar*
}

Recent research on unmet legal need in Canada suggests that access to justice problems may represent a latent market for some legal services. But there is relatively little Canadian research on how lawyers organize and run their practices, and on how those practices could improve access to justice. This paper provides a case study of Pivot Legal LLP, an innovative law firm in Vancouver's Downtown Eastside neighbourhood that aimed to improve access to justice for community members. Interviews with the lawyers involved suggest that a similar firm could survive and thrive in the future. These findings have implications for legal entrepreneurs, and also for how the legal profession and the legal academy could better support practice-level innovations to improve access to justice in Canada.

Selon de récentes recherches sur les besoins juridiques non comblés au Canada, les problèmes d'accès à la justice pourraient représenter un marché latent dans le cas de certains services juridiques. Cependant, peu de recherches ont été menées au Canada sur la façon dont les avocats s'organisent et gèrent leurs cabinets et la façon dont ces pratiques pourraient permettre d'améliorer l'accès à la justice. Ce document traite d'une étude du cabinet Pivot Legal LLP - cabinet d'avocats innovateur situé à proximité de la partie Est du centre-ville de Vancouver - qui vise à améliorer l'accès à la justice pour les membres de la collectivité. De l'avis des différents avocats concernés qui ont été interrogés, un cabinet similaire pourrait survivre, voire prospérer au cours des années à venir. Ces constatations ont des incidences pour les entrepreneurs juridiques ainsi qu'en ce qui a trait aux moyens que les membres de la profession juridique et les professeurs de droit pourraient utiliser pour mieux appuyer les innovations de la pratique susceptibles d'améliorer l'accès à la justice au Canada.

Andrew Pilliar, PhD student, Faculty of Law, University of British Columbia (UBC). The empirical research contained in this article was approved by the University of British Columbia's Behavioural Research Ethics Board, Certificate of Approval H12-00230. I owe a debt of gratitude to the former lawyers, staff, and advisors of Pivot Legal LLP who gave generously of their time to allow me to interview them. Thanks also to my supervisor, Professor Mary Liston, my second reader, Professor Michael Trebilcock, and to Professor Emma Cunliffe. Thanks also to Jennifer Spencer, Jamie Maclaren, Robin Sidsworth, Jerry McHale, Q.C., Aleha McCauley, Leonard T. Doust, Q.C., Professor Darlene Johnston, Dean Lorne Sossin, the UBC LLM class of 2011/2012, Anna Lund, Will Damon, and Elliot Siemiatycki for helpful conversations and comments on this research. I would also like to thank an anonymous peer review reader for helpful comments on a previous draft. An extended version of this paper was accepted as my LLM thesis by the University of British Columbia in October 2012. 


\section{INTRODUCTION}

Over the past 15 years, research on unmet legal need in Canada and around the world has demonstrated that while legal problems are prevalent in the lives of many citizens, relatively few people access legal services to deal with those problems. ${ }^{1}$ Access to justice has been called "the most significant challenge to our justice system", and the issue has featured prominently in public remarks of prominent jurists and members of the legal profession across Canada. ${ }^{2}$ In 2013, two major reports on access to justice problems in Canada, one by the Canadian Bar Association (CBA) and one by the Action Committee on Access to Justice in Civil and Family Matters, made significant recommendations to deal with access problems. ${ }^{3}$

These recommendations have included calls for the justice system to focus on users, for a cultural shift in the legal profession and innovation in the institutions of the legal system, and for widespread public education about legal matters, among others. ${ }^{4}$ They have also touched on how technological change and shifts in the regulatory framework of the legal profession may affect access to justice matters. ${ }^{5}$ But there has been relatively little discussion of how lawyers and others could design and operate their everyday practices to improve access to justice. Is it possible for legal service providers to design and run viable firms that cater to the apparently latent demand for legal services suggested by unmet legal need studies?

There is a dearth of information about how lawyers might actually go about providing services to low- and middle-income earners. This article takes a step to fill that gap by detailing a case study of a novel legal practice in Vancouver's Downtown Eastside neighbourhood that, for four years, provided legal services as a full-service law firm. This firm, Pivot Legal LLP (the LLP) was set up by the founders of the well-known Pivot Legal Society (PLS). PLS is known for its work in social justice matters and strategic litigation over the last decade. ${ }^{6}$ The case study explores how the LLP worked, attempts to explain why it ultimately folded, and draws conclusions that may be of benefit to other lawyers interested in providing accessible legal services. Ultimately, it is possible, but quite difficult, to

1 See, for example, Pascoe Pleasence \& Nigel J Balmer, "Caught in the Middle: Justiciable Problems and the Use of Lawyers" in Michael Trebilcock, Anthony Duggan, \& Lorne Sossin, eds, Middle Income Access to Justice (Toronto: University of Toronto Press, 2012) 27.

2 The Right Honourable Beverley McLachlin, "Foreword" in Michael Trebilcock, Anthony Duggan, \& Lorne Sossin, eds, Middle Income Access to Justice (Toronto: University of Toronto Press, 2012) ix at ix; the Hon Lance Finch, "Access to Justice: The Elephant in the Room" (Address delivered at the Canadian Bar Association's British Columbia Branch meeting in Scottsdale, AZ, 20 November 2010), [unpublished].

3 Canadian Bar Association Access to Justice Committee, Reaching Equal Justice: An Invitation to Envision and Act, Final Report (Ottawa: Canadian Bar Association, 2013) [Reaching Equal Justice]; Action Committee on Access to Justice in Civil and Family Matters, Access to Civil and Family Justice: A Roadmap for Change (Ottawa: Action Committee on Access to Justice in Civil and Family Matters, 2013) [Roadmap for Change].

4 Reaching Equal Justice, supra note 3 at 60-64, 82; Roadmap for Change, supra note 3 at 2, 5, 7.

5 Ibid.

6 See, for example, Canada (AG) v. PHS Community Services Society, 2011 SCC 44, [2011] 3 SCR 134, [2011] SCJ no 44 (QL); Canada (AG) v. Downtown Eastside Sex Workers United Against Violence Society, 2012 SCC 45, [2012] 2 SCR 524, [2012] SCJ no 45 (QL). 
run an innovative law firm that tries to address access to justice problems in Canada. This article also explores how such innovation could be better supported.

In Part II, I will briefly review the scope of access to justice problems in Canada. In Part III, I will explore some literature on lawyers' practices, and explain why understanding how lawyers practice is an important aspect of addressing access to justice problems. Part IV is the case study of Pivot Legal LLP, including both a description of what the LLP was, and offering some explanations of what worked and what didn't work. In Part V, I discuss some possible lessons that can be drawn from the case study to improve access to justice.

\section{ACCESS TO JUSTICE IN CANADA}

Since the mid-1990s, largely in the wake of Hazel Genn's pioneering work in England and Wales, empirical research on legal need has proliferated. Research in this tradition has provided the most comprehensive way of understanding unmet legal need, and studies have been conducted in 23 national surveys, spanning 13 countries. $^{7}$

A recent international comparative study suggests that access to civil justice is the most pressing problem facing the Canadian justice system. Canada ranked 16th out of 23 high income countries for access to civil justice, and ninth out of 12 high income countries in North America and Western Europe. ${ }^{8}$

The leading study of unmet legal need across Canada is Ab Currie's 2006 study. ${ }^{9}$ Currie's research is methodologically similar to the previous work of Genn and others. Currie's study investigated the incidence of justiciable events among Canadians. The study also probed connections between problems, effects of the problems, socio-demographic information, and general attitudes toward society and the legal system. ${ }^{10}$

Other notable recent studies of unmet legal need in Canada have been narrower in geographic scope than Currie's study. In 2009, the Ontario Civil Legal Needs Project surveyed low- and middle-income Ontarians, publishing its findings in 2010. ${ }^{11}$ In British Columbia, the Legal Services Society [LSS] commissioned an online opinion poll of everyday legal problems in 2008. This survey drew on responses from respondents over the age of 18 and with household incomes below $\$ 50,000$ annually. ${ }^{12}$

$7 \quad$ Pleasence \& Balmer, supra note 1 at 28.

8 Mark Agrast, Juan Botero \& Alejandro Ponce, World Justice Project: Rule of Law Index 2011 (Washington, D.C.: The World Justice Project, 2011) at 23, 51.

9 Ab Currie, Department of Justice, The Legal Problems of Everyday Life: The Nature, Extent and Consequences of Justiciable Problems Experienced by Canadians (Ottawa: Department of Justice, 2007) at 10, 60, online: Department of Justice <http://www.justice.gc.ca/eng/rp-pr/csj-sjc/jsp-sjp/rr07_la1rr07_aj1/index.html>.

10 Ibid at 6 .

11 Listening to Ontarians: Report of the Ontario Civil Legal Needs Project (Toronto: Ontario Civil Legal Needs Project Steering Committee, 2010) (Chair: R Roy McMurtry) at 64-65.

12 "Legal Problems Faced in Everyday Lives of British Columbians", (2 December 2008), online: Legal Services Society $<$ http://www.lss.bc.ca/assets/aboutUs/reports/legalAid/IPSOS_Reid_Poll_Dec08.pdf $>$ [LSS Survey]. 
Currie's survey estimated that "out of the 25.9 million Canadians aged 18 and older, about 11.6 million experienced at least one justiciable event or problem during the three-year reference period." "That is, $44.6 \%$ of all respondents experienced one or more justiciable events, with those reporting justiciable events experiencing three events, on average. ${ }^{14}$ This illustrates the ubiquity of justiciable problems among Canadian adults.

Currie also noted that some vulnerable groups, not surprisingly, experience higher incidence rates of justiciable events than the population at large. Currie identified Aboriginal people, foreign-born individuals, members of visible minorities, people with self-reported disabilities, and those receiving social assistance in particular. A multivariate analysis indicated that "being disabled is a significant predictor of all" types of legal problems studied. ${ }^{15}$

In further analyzing the effect of justiciable problems on the lives of individuals, Currie's study examined the monetary value associated with certain types of problems, such as consumer problems and debt problems. For many of these problems, the amount of money involved was quite low: in the hundreds or low thousands of dollars. Currie noted that "[s]ensible ways of resolving problems involving these amounts of money would probably not include engaging private counsel at normal rates." "Yet at the same time, people indicated that they attached high importance to resolving these problems. While this importance appeared to be directly related to the amount of money involved, even problems which involved low amounts were rated as important to the people dealing with them. ${ }^{17}$

Turning to the question of how people respond to problems, Currie found that most Canadians dealt with their problems alone, without any form of assistance. Currie reported that $44 \%$ of respondents with a justiciable problem handled the problem on their own, while $22.1 \%$ of respondents dealt with the problem with non-legal assistance. $11.7 \%$ of respondents dealt with their problem with some legal assistance. $^{18}$

Of the $9.2 \%$ of respondents to Currie's study who sought legal assistance, $79.8 \%$ did so from a private lawyer, while $9.6 \%$ turned to legal aid. Legal assistance was used most frequently for family law matters, but was used infrequently for discrimination, consumer, employment, social assistance, and debt problems (less than 10\% in each case). Legal assistance was sought between 14 and $20 \%$ of cases for matters related to immigration, personal injury, disability benefits, housing, police action, and wills and power of attorney matters. ${ }^{19}$

Currie's research does not test why respondents chose to deal with matters on their own. In Hazel Genn's pioneering Paths to Justice study, however, follow-up research suggested that perception of high costs for lawyers was a significant factor cited by respondents in avoiding the justice system in England

\footnotetext{
Supra note 9 at $10-11$.

Ibid.

Ibid at 23-26.

Ibid at 39.

Ibid at 38-40.

Ibid at 56.

Ibid at 60-61.
} 
and Wales. ${ }^{20}$ Genn notes that perceptions of legal costs came both from personal experiences and from media reports. ${ }^{21}$

\section{LAWYERS' PRACTICES}

Against this background of pervasive unmet need, one might think that lawyers would begin adapting their practices to meet this need. Yet given the accounts of access to justice presented in the CBA report, this adaptation does not appear widespread. ${ }^{22}$ Moreover, there has been relatively little work on how lawyers' practice organization affects access to justice. ${ }^{23}$

The lack of detailed work on how lawyers might provide legal services to address unmet legal need is a significant omission. If lawyers can provide legal services in innovative ways that improve access to justice, those efforts should be encouraged. But it is important to understand in detail what obstacles lawyers face in attempting to provide more accessible services.

Writing about the United States, Luz Herrera has described the business models of solo lawyers who operate virtual law firms to provide personalized forms and unbundled services to otherwise selfrepresented litigants and low- and moderate-income clients. ${ }^{24}$ She notes that although the majority of lawyers in private practice are self-employed, "few law graduates enter the profession understanding the opportunities and challenges of starting their own law firms." 25

In previous decades, other researchers have described how lawyers have recognized and responded to unmet legal needs in their communities. In the 1990s, Carroll Seron's study of solo and small firm lawyers in New York City detailed how practice settings helped constitute lawyers' notions of professionalism, as well as how they responded to perceived need. ${ }^{26}$ In addition, work by Louise Trubek and Elizabeth Kransberger has explored how critical lawyers in private practice took steps in small firm settings to empower their clients and challenge traditional models of law firm organization in order to improve access to justice. ${ }^{27}$

But in Canada in 2015, there is relatively little discussion of how lawyers could design their practices and their careers to respond to the greatest challenge facing the justice system. This silence is curious, but is also an impediment to some of the very innovation that the CBA and National Action Committee reports have called for.

20 Hazel Genn, Paths to Justice: What People Do and Think about Going to Law (Oxford, UK: Hart Publishing, 1999) at 233-239.

21 Ibid at 237-238.

22 Reaching Equal Justice, supra note 3 at 52.

23 Ibid at 99.

24 Luz E Herrera, “Training Lawyer-Entrepreneurs” (2012) 89 Denv UL Rev 887 at 899-900.

25 Ibid at 889.

26 Carroll Seron, The Business of Practicing Law: The Work Lives of Solo and Small-Firm Attorneys (Philadelphia: Temple University Press, 1996).

27 Louise Trubek \& M Elizabeth Kransberger, "Critical Lawyers: Social Justice and the Structures of Private Practice" in Austin Sarat \& Stuart Scheingold, eds, Cause Lawyering: Political Commitments and Professional Responsibilities (Oxford: Oxford University Press, 1998) 201. 
Herrera argues forcefully that law students and lawyers should be encouraged to take entrepreneurial steps to practice law to improve access to justice, and suggests that there is opportunity for solo and small firm practitioners to lead this change.$^{28}$ She argues that solo practice "is more than a career path of last resort. It is the most enduring segment of the bar that has consistently helped individuals in our society navigate the democratic legal system we live in., ${ }^{29}$

There are other reasons to suppose that law students should embrace careers outside large law firms catering to corporate and institutional clients. A recent study found that lawyers working in "service" positions, such as public defence, legal aid lawyers, and public agency lawyers, demonstrated more markers of general well-being than lawyers working in "money" positions, which were characterized by high levels of prestige and income, such as working at a very large law firm or doing commercial/business/securities-related legal work. ${ }^{30}$ Opportunities to find sustainable, rewarding careers should appeal to thoughtful new lawyers.

In suggesting that an innovative type of law firm can help improve access to civil justice, I do not mean to suggest that this is a panacea. Nor do I suggest that government should be excused from its obligations to improve access. Rather, I incline to the view that access to justice must be improved through a continuum of programs and efforts. ${ }^{31}$ At present, discussion of business model innovation is largely missing from that continuum. The case study of Pivot Legal LLP begins to remedy that problem.

\section{PIVOT LEGAL LLP}

Pivot Legal LLP was founded as a multi-service law firm in 2006, and was situated in Vancouver's Downtown Eastside neighbourhood. This neighbourhood, one of the oldest in Vancouver, is sometimes referred to as "the poorest postal code in Canada". ${ }^{32}$ The LLP grew out of Pivot Legal Society, a nonprofit legal advocacy society that has been active in the Downtown Eastside for over a decade. PLS focusses on issue advocacy and strategic litigation, and its past work has included high profile legal and media work on issues including policing, housing, sex work, violence against women and drug policy, by using combinations of public advocacy and litigation to advance these causes. ${ }^{33}$

The LLP was set up to provide legal services for individuals and organizations with everyday legal needs, and also to provide a source of steady funding for PLS. ${ }^{34}$ The LLP was also founded to show

28 Herrera, supra note 24 at 898.

29 Ibid.

30 Kennon M Sheldon \& Lawrence S Krieger, "Service Job Lawyers are Happier than Money Job Lawyers, Despite their Lower Income" (2014) 9:3 Journal of Positive Psychology 219 at 220, 223-224.

31 Currie, supra note 9 at 90.

32 Douglas Coupland, City of Glass: Doug Coupland's Vancouver, (Vancouver: Douglas \& McIntyre, 2003) at 87.

33 John Richardson, “A History of Pivot Legal Society”, in Brad Cran \& Gillian Jerome, eds, Hope in Shadows: Stories and Photographs of Vancouver's Downtown Eastside (Vancouver: Arsenal Pulp Press, 2008) 18 at 18-31.

34 In describing the legal needs dealt with by Pivot LLP as "everyday", I do not mean to deprecate their importance to those individuals. Rather, I attempt only to draw a line between legal problems that might be picked up as part of Pivot Legal Society's strategic litigation work - such as the two cases mentioned which 
how a fresh, innovative law firm could both provide meaningful legal services in its community and break from conventional, hierarchical ways of running a law firm. It won an award as one of the most promising social enterprises in Vancouver, and had grown to 12 lawyers within two years. ${ }^{35}$ But by the end of 2010, the LLP was no more.

Between March and June 2012, I conducted face-to-face interviews with nine individuals who were involved with the LLP. In addition, I was granted access to some of the business records of the firm, in order to understand how it operated and try to draw conclusions about why it ultimately closed down. The interview participants included former partners, former lawyers, administrative support staff, and external advisors. All references to the identities of these individuals or to identifiable characteristics have been redacted to preserve their anonymity.

The idea for the LLP emerged in 2004. ${ }^{36}$ Originally, the law firm was intended to act as a fundraising tool for PLS. ${ }^{37}$ By selling a broad range of legal services, the LLP would provide a steady source of funding for PLS that was independent of government and also independent of other funding bodies.

Many lawyers also appear to have been attracted to the LLP because of its ties to PLS and the work done by PLS. As one partner described it,

...we had lawyers who came to work for the LLP... because they wanted to represent individuals who needed help and... part of their social change work was representing refugees, representing low income people in civil suits against police. They were very committed to that... and so they were saying "no I'm not going to turn away clients and files that don't pay well, because that's why I'm here."”8

The LLP started with three lawyers as partners. ${ }^{39}$ A fourth partner joined the LLP approximately one year after its doors opened. ${ }^{40}$

While the initial stated goal of the LLP was to fund PLS, the actual goals of the LLP appear to have been several, and to have changed slightly over time. ${ }^{41}$ Each of the four partners identified the original goal of the LLP as providing a source of funding for PLS. ${ }^{42}$ One of the partners described the origin of the LLP as follows:

[Two of the partners] had had a conversation about stable funding that was separate from granting agencies who had onerous reporting requirements, and separate from

went to the Supreme Court of Canada - and legal problems experienced on a daily basis by individuals - such as debt or credit matters, harassment claims, etc. - that would fit with the mandate of Pivot Legal LLP. events/2010-social-enterprise-dragons/ $>$ [Social Enterprise Dragons]. Interview of Partner 4 (June 5, 2012)[Partner 4]; Interview of Partner 3 (March 30, 2012) [Partner 3]. Partner 4, ibid. Partner 3, supra note 36. Partner 3, ibid; Interview of Partner 1 (May 16, 2012)[Partner 1]. Interview of Partner 2 (May 4, 2012) [Partner 2A]; Partner 3, supra note 36. Milton Kiang, “'Unique model' for public service work”, The Lawyers Weekly (22 May 2009) 18. Partner 4, supra note 36; Partner 3, supra note 36; Partner 1, supra note 39; Partner 2A, supra note 40. 
government so that the organization could maintain independence, and wasn't so reliant on the sympathies of rich people, and basically to try to avoid all the pitfalls of traditional fundraising. So they were looking at social enterprise models and were like "we could do bake sales or a carwash" and joking around, but then it sort of hit them, we're lawyers. We could sell legal services for money and it's a huge market and there are significant markups and you can make a fair amount of dough doing it. So we could stream income from the law firm to the non-profit and support that work. And not only that, it would give us a whole bunch of lawyers working for the organization indirectly who could also bring their expertise to bear on pro bono cases and whatever else. So that's where it came from. ${ }^{43}$

As the LLP grew, its goals also seemed to shift slightly; as one partner described it, the LLP "accumulated associated goals". ${ }^{44}$ Other goals identified by the partners included:

1. developing legal expertise among lawyers who could provide that expertise to PLS; ${ }^{45}$

2. providing a supportive workplace for employees, including adopting a flattened and consultative decision-making model; ${ }^{46}$

3. completely re-working how legal services are delivered; ${ }^{47}$ and

4. providing affordable legal services. $^{48}$

The last of these, providing affordable legal services, was cited by virtually all interview participants. ${ }^{49}$ The development of this "associated goal" was described as follows by one of the lawyers:

[Funding PLS was] the very initial goal. But then I personally, and I think others also, took it as the work that we're doing in the law firm isn't just about providing money for funding [PLS], but we're also serving particular communities that, at least in my case, I felt like I was serving particular communities that were not well represented, and that if some of the profit from that could go back into the work that the Society was doing then great, but also it in and of itself was important work to do. ${ }^{50}$

Another important aspect of the LLP was the partners' ambition to create a "flat" organizational structure, so that decision-making authority would be shared among all staff, and the most senior lawyer

43 Partner 1, supra note 39.

44 Partner 4, supra note 36.

45 Partner 4, ibid; Partner 3, supra note 36.

46 Partner 1, supra note 39; Partner 3, ibid; Partner 2A, supra note 40.

47 Partner 1, supra note 39; Partner 3, supra note 36.

48 Partner 3, ibid.

49 Interview of Advisor 1 (May 24, 2012) [Advisor 1]; Partner 1, supra note 39; Partner 4, supra note 36; Partner 3, supra note 36; Interview of Associate 2 (May 25, 2012) [Associate 2]; Partner 2A, supra note 40; Interview of Associate 3 (May 29, 2012) [Associate 3].

50 Associate 2, supra note 49. 
would not make significantly more than the most junior staff. ${ }^{51}$ Originally, the partners hoped to structure the LLP as a co-operative, whereby lawyers and staff would share decision-making power, and each would have a similar ownership interest in the organization. ${ }^{52}$ The idea of a co-operative, however, was ultimately foiled by Law Society of British Columbia regulations prohibiting ownership of a law firm by non-lawyers. ${ }^{53}$ Ultimately, the LLP started as a limited liability partnership, with a legal management corporation commenced simultaneously to handle the administrative needs of the law firm as it grew. The legal management corporation was never very active because the LLP did not grow large enough or last long enough to use this separate management structure. ${ }^{54}$

At the outset, the LLP conducted a survey of the legal marketplace in Vancouver, and worked with several business, accounting, and marketing experts before it opened its doors in the Fall of $2006 .{ }^{55}$ Based on the market survey, which indicated an average price for civil legal services of approximately $\$ 300$ per hour, the LLP hoped to situate itself below the market average by charging $\$ 100$ to $\$ 200$ per hour for legal services. ${ }^{56}$

The LLP started doing work in criminal law, immigration and refugee matters, human rights work, and some additional civil litigation. ${ }^{57}$ After approximately one year, it added its fourth partner, who commenced a solicitor's practice, focussing on business matters (i.e. incorporations, preparing shareholders agreements, etc.).

To understand the LLP's revenue sources, it is essential to understand the structure of the LLP's relationship with its lawyers. Initially, the LLP started with three partners, two additional lawyers under salary, and one support staff. ${ }^{58}$ It shared its physical space with PLS, and arranged to pay rent to PLS. ${ }^{59}$ Funding for the LLP was initially provided in the form of low-interest loans, which were jointly held by the partners and guaranteed by PLS. ${ }^{60}$

The LLP grew quickly by adding lawyers. The LLP typically attracted lawyers in the one to five year call range. ${ }^{61}$ However, the LLP did not add lawyers as typical employees. These lawyers entered an "associates' agreement" with the LLP, whereby they were granted space in the LLP's office in exchange for a portion of their billings. ${ }^{62}$ The associates were permitted to set their own rates. ${ }^{63}$ The associates' agreement changed a number of times over the life of the LLP. ${ }^{64}$

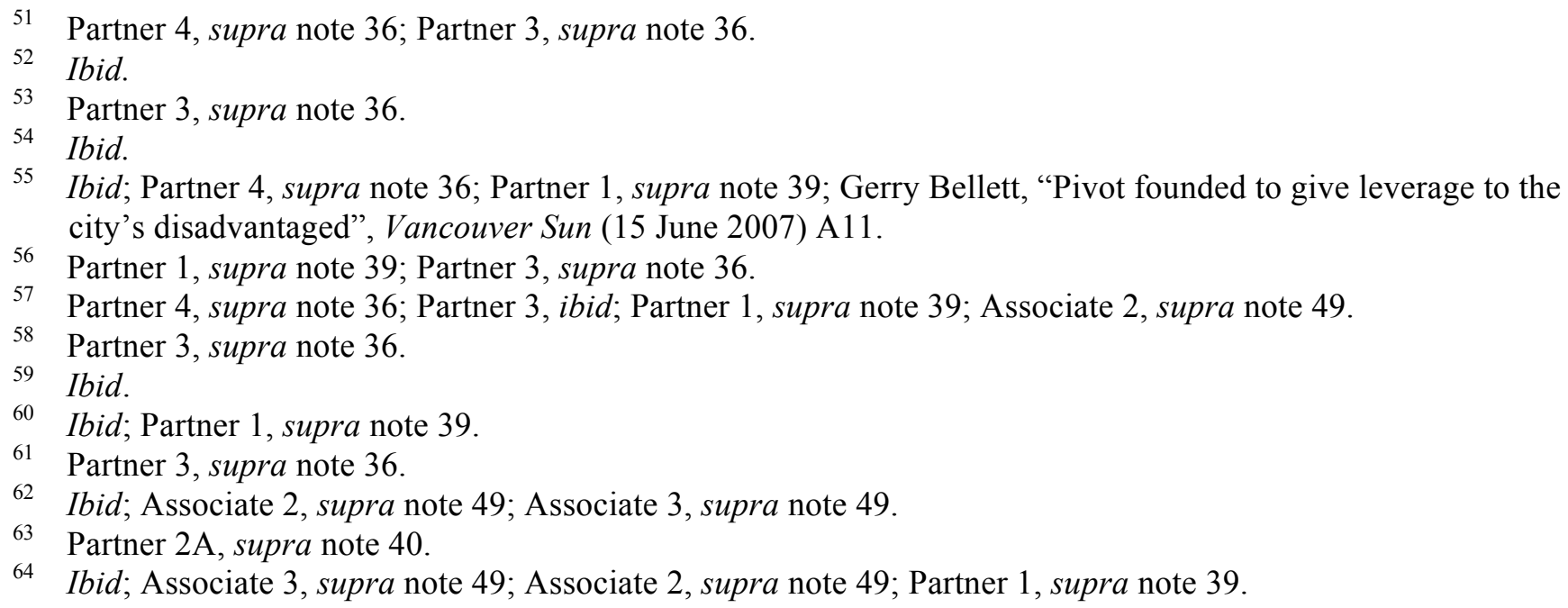


At its largest, the LLP consisted of at least a dozen lawyers, with two support staff. ${ }^{65}$ Part of the reason for the LLP's growth was to ensure that it provided a sufficiently broad range of legal services to capitalize on available opportunities. ${ }^{66}$ Accordingly, the LLP grew to include criminal defence, family law, personal injury and civil litigation, business law, non-profit law, foundations and charity law, immigration and refugee law, administrative law, wills and estates law, labour law, employment and workers compensation claims, human rights complaints, real estate law, and aboriginal residential school survivor claims. $^{67}$

A second reason for the LLP's growth was to both utilize and pay for the rather large space that the LLP rented from PLS. ${ }^{68}$ The partners expected that associates would create revenue that would help to cover the LLP's rent, among other overhead costs. ${ }^{69}$

One of the partners described a typical work day at the LLP as being "a bit nine to five",70, and less than that at large law firms. In contrast, two of the lawyers who worked there described working as many hours, or more, at the LLP as they did in private practice. ${ }^{71}$ As one described it: "I worked more hours at Pivot then I did at [a mid-sized regional law firm] over the same period. And that says a lot." 72 There appears, however, to have been significant variation between lawyers ${ }^{73}$, and there may also have been variance at different times over the lifespan of the $\operatorname{LLP}^{74}$. As one lawyer described it:

Eventually I had about 60 files. I was supposed to be doing part time civil litigation, because I was working part-time for the Society. But then to make a financial go at it, you can't really have a half-time practice. So really at the end of the day, I worked seven days a week, by the end, every day, for three or four months. So when I would take a Friday afternoon off once in a while... I still had gone in... I don't remember taking a day off until I went on holiday in April, after starting in May. Like a full year. It started off really slowly, and really well, but by the end it was just gruelling and had encompassed everything. 75

Many lawyers worked from home or were not regularly present at the LLP's office. ${ }^{76}$

\footnotetext{
65 Interview of Staff 1 (May 26, 2012) [Staff 1].

66 Partner 4, supra note 36; Partner 2A, supra note 40.

67 Partner 3, supra note 36; Partner 2A, ibid; Associate 2, supra note 49; Associate 3, supra note 49; "Pivot Legal LLP Grant Application" (2010) [unpublished].

68 Partner 4, supra note 36; Partner 3, supra note 36.

69 Partner 1, supra note 39; Partner 2A, supra note 40.

70 Interview of Partner 2 (May 17, 2012) [Partner 2B].

71 Associate 3, supra note 49; Associate 2, supra note 49.

72 Associate 3, supra note 49.

73 Staff 1, supra note 65.

74 Associate 2, supra note 49.

75 Associate 3, supra note 49.

76 Partner 2B, supra note 70.
} 
During the course of its operations, the LLP provided legal services to 1381 clients. In the view of several of the partners, many of these clients would likely not have obtained any legal services if the LLP had not existed. ${ }^{77}$

Although the LLP never succeeded in fulfilling one of its goals - funding PLS - it was able to meet another goal: providing legal services to those who could not otherwise afford them.

\section{A. Why the LLP Didn't Succeed}

At a very basic level, the LLP was forced to close because its expenses exceeded its revenues. The reasons for this state of affairs are more complex than this, of course. But framing the LLP's problems in terms of revenues and expenses at least provides an analytical framework in which to examine these various, complex factors. Understanding these factors is important to not only understand why the LLP was not sustainable, but to design a business model that is sustainable.

While this case study cannot ground conclusions about causal relationships between the LLP's apparent problems and its ultimate downfall, it is possible to speculate about possible relationships based on analysis of the interviews and the LLP's business records.

This section will review a constellation of factors that appear to have contributed to the LLP's difficulties. First, I will describe some of the expenses that the LLP was saddled with, and which ultimately contributed to the firm's demise. Specifically, the LLP took on debt, became tied to an onerous office lease, and developed an operational structure that contributed to high overhead costs. Next, I will turn to the LLP's challenges in generating revenue, focussing particularly on the LLP's lack of existing clients, its difficulties in attracting new clients, a problematic mix of file types, and staffing problems that impeded revenue generation.

\section{Expenses}

The LLP's expenses always exceeded its revenues. ${ }^{78}$ While this might reflect insufficient revenue, it also suggests that the LLP was burdened with significant structural expenses from the start.

At the outset, the LLP took on debt from friendly lenders who offered good rates and tended to work with the LLP to develop its business model. ${ }^{79}$ This initial debt allowed the LLP to pay upfront for some business expenses, but it also seems to have contributed to setting the LLP on an economically unsustainable path. Although debt payments were on relatively good terms and the total debt does not seem to have been particularly onerous in the context of the LLP's total operation, debt was cited by several partners as a factor in the LLP's ultimate demise. ${ }^{80}$ This seems to have operated in several ways: debt servicing costs prevented lawyers with profitable businesses from joining or staying with the LLP $^{81}$, and created an unwanted external billing pressure on the LLP. ${ }^{82}$ Ultimately, the LLP was not able to fully repay all of its lenders. ${ }^{83}$

77 Partner 3, supra note 36; Partner 4, supra note 36.

78 "Pivot Legal LLP Business Records - 2009-2011" (17 July 2012) [unpublished] [Business Records].

79 Partner 3, supra note 36.

80 Business Records, supra note 78; Partner 3, ibid; Partner 1, supra note 39; Partner 2A, supra note 40.

81 Partner 2A, ibid.

82 Partner 3, supra note 36.

83 Interview of Advisor 2 (April 30, 2012) [Advisor 2]; Partner 4, supra note 36. 
Another significant expense for the LLP was its lease. The LLP shared space with PLS, which had an ownership interest in a building on East Hastings Street in Vancouver. ${ }^{84}$ In 2009 and 2010, rent was the second highest single expense for the LLP, after only personnel costs. ${ }^{85}$ Rent was described as "a killer" by one of the partners: rent accounted for almost 14\% of total revenue in 2009 and $2010 .{ }^{86}$ Burdened with large premises, the lease also created pressure on the partners to fill all available space, thereby forcing the LLP to grow faster than was advisable. ${ }^{87}$

The largest annual expense for the LLP, as for almost any professional services firm, was payroll. Because the LLP did not pay salaries to its associates, it appears to have recorded its payroll obligations in two ways: payments to associates are recorded as "associates fees", while payments to employees presumably the partners and office staff - are recorded as "wages/source deductions". 88

The LLP added associates quickly to ensure that it provided a sufficiently broad range of legal services to capitalize on available opportunities. ${ }^{89}$ This assumed that the LLP would have demand across those practice areas, and that those associates would also bring in business. Unfortunately, as is discussed in the following section, these projections were unduly optimistic. ${ }^{90}$

\section{Revenue}

The LLP did generate revenue. By 2009 , for example, it was generating $\$ 100,000$ in billings in the first three months of the year. ${ }^{91}$ The LLP's business records for 2009 record total billed fees in excess of $\$ 330,000$, by far the LLP's biggest source of income. ${ }^{92}$ However, interview participants suggested that the LLP did not generate as much revenue as was necessary to meet their initial business plans. ${ }^{93}$

The LLP's lawyers were, at times, busy. ${ }^{94}$ Unfortunately, this busy-ness did not translate into paying business. Despite the partners' optimistic projections of revenue, reality proved more difficult:

We said let's assume that every lawyer is able to bill 15 hours a week at our maximum billing rate, which was like $\$ 150$ an hour, and we were like "oh my God, we're going to be rich!" And 15 hours a week is not a lot of billable hours for a lawyer. ... And we did a market survey and everybody else is charging $\$ 300$ an hour. And the scope is reasonable. 15 hours a week is totally achievable, and everything flows from that: salary, admin staff, and all of that. And everybody around the table nodded their heads and

\footnotetext{
84 Partner 4, ibid; Advisor 2, supra note 83; Kiang, supra note 41.

85 Business Records, supra note 78.

86 Partner 4, supra note 36.

87 Ibid; Partner 3, supra note 36; Advisor 1, supra note 49.

88 Business Records, supra note 78.

89 Partner 4, supra note 36; Partner 2A, supra note 40.

90 Partner 1, supra note 39.

91 Kiang, supra note 41.

92 Business Records, supra note 78.

93 Partner 1, supra note 39.

94 Ibid.
} 
agreed. But you know, most of our lawyers, even in their best weeks, would do five or 10 billable hours a week. And the rest of the time was unbilled time. ${ }^{95}$

What explains the discrepancy between the LLP's projected and actual revenues? Four aspects were identified by interview participants: lack of existing clients, problems cultivating new paying clients, a problematic mix of files, and staffing problems.

The absence of lawyers with existing, paying clients was a problem generally for the LLP. At the outset, only one of the partners had any kind of established practice. ${ }^{96}$ In retrospect, at least one interview participant commented that all of the partners should have been able to generate income from the start. ${ }^{97}$ When, later in the LLP's existence, the partners tried to take steps to bring in a lawyer with existing clients, they ran into push-back from associates because the proposed lawyer's practice area did not fit with the firm's socially progressive values. ${ }^{98}$

The LLP also had problems in cultivating new clients. A number of partners commented that despite the LLP's wide breadth of practice, some expected clients did not materialize. The LLP's business was a greater proportion of community members seeking personal legal services - who often could not afford to pay much or anything - than expected, and a lower proportion of paying businesses or not-forprofits. One lawyer described having a practice in which "80 to $90 \%$ were low income or Downtown Eastside residents." 99 This sense of surprise is reflected in the comments of one partner:

I was surprised by who really didn't come in for us. We really expected when we opened up we would immediately have a large number of socially progressive businesses... but they didn't really show up. The unions - we thought we would be able to get a piece of their work here and there, but they didn't show up until much later, in fact when it was too late unfortunately. And we thought that we might get some work from [a progressive financial institution], and we did get one piece from them, but it was really crazy beyond our capabilities so that was the end of that. So that was the people who didn't show up. ${ }^{100}$

Interview participants offered seven distinct potential explanations for the LLP's failure to secure expected business. These included:

- Expected clients didn't actually have legal needs; ${ }^{101}$

- Potential clients had existing counsel; ${ }^{102}$

- Perceived cost of lawyers, ${ }^{103}$

95 Ibid.

96 Partner 3, supra note 36.

97 Ibid.

98 Associate 3, supra note 49.

99 Ibid.

100 Partner 1, supra note 39.

101 Partner 4, supra note 36.

102 Partner 1, supra note 39; Partner 2A, supra note 40.

103 Partner 4, supra note 36. 
- Concern about the inexperience of LLP lawyers; $;{ }^{104}$

- LLP lawyers appeared "too desperate"; 105

- Branding confusion between the LLP and PLS; ${ }^{106}$ and

- Legal conflicts. ${ }^{107}$

The devastating cuts to legal aid that were made in British Columbia in 2002 were also cited as a significant impediment to developing steady income streams, especially for young lawyers. ${ }^{108}$ Assessing the relative merit of these explanations is challenging, and further research on this issue would be instructive.

Despite the fact that the LLP engaged in extensive business planning, both at the outset and during its operations, all of this planning seems to have been of very limited value in generating paying clients. As one of the partners noted ruefully, many of the business plans were "largely aspirational" when it came to revenues. ${ }^{109}$ Another partner, who did solicitor work and expected to work for businesses and notfor-profit organizations, commented on not being as busy as expected. ${ }^{110}$

This raises serious questions about how well legal professionals understand why their clients or potential clients choose counsel. Several of the partners remarked on the importance of proven competence as the number one criterion for sophisticated clients. ${ }^{111}$ One partner suggested that perceived lawyer competence appeared to be the sole driver for many paying clients, instead of value or ethical alignment between lawyers and clients. ${ }^{112}$ This view was corroborated by one of the LLP's advisors, who indicated that his criteria for hiring a lawyer were "success and competence, number one". ${ }^{113}$

Some interview participants indicated that because the LLP attracted lawyers interested in doing social justice work, those lawyers were often not effective at cultivating paying clients. ${ }^{114}$ This seems to have been a major surprise for the partners. The LLP took on associates premised on the belief that they would earn money and then be able to pay a percentage of their earnings to cover the LLP's overhead. However, many associates "were very optimistic about their ability to bill and it didn't materialize."115 As one lawyer noted, associates were not always given much support to develop business: "I don't remember having any [business planning assistance] while I was there. I don't remember ever having a plan. I feel like I created an ad hoc plan myself, and in retrospect it was completely unrealistic. But I did

\footnotetext{
104 Advisor 2, supra note 83

105 Partner 1, supra note 39.

106 Partner 3, supra note 36.

107 Partner 1, supra note 39.

108 Ibid.

109 Ibid; Partner 3, supra note 36; Partner 4, supra note 36; Advisor 2, supra note 83.

110 Partner 2B, supra note 70.

111 Partner 3, supra note 36; Partner 1, supra note 39; Partner 4, supra note 36.

112 Partner 3, supra note 36.

113 Advisor 2, supra note 83.

114 Partner 4, supra note 36.

115 Partner 2A, supra note 40.
} 
that for myself." 116 Many of the associates did not earn enough to support themselves or cover the LLP's costs. ${ }^{117}$

The LLP seemed to attract young lawyers who were disillusioned with the typical practice of law. This is not surprising, since reforming the typical practice structure was one of the goals of the LLP, cited by several of the partners. ${ }^{118}$ The LLP "attracted a lot of lawyers who had gone to firms and were disillusioned and wanted to do something different." ${ }^{\text {"19 }}$ But to the extent that these lawyers were no longer interested in practicing law, this likely posed a significant hurdle for the LLP's success. As one lawyer commented: "as time went on, people were also coming who were fed up with legal practice. So that's also strange, because in fact, there was no difference. You were still going to have to do it. You would still have to practice law." $" 120$

While it is probably accurate to observe that the LLP needed more lawyers who were motivated to bring in paying clients, it is important to recognize that some lawyers - including those with a professed interest in social justice work - grew into their practices and their abilities to develop clients. For example, one lawyer, after discussing her interest in public interest matters and stating that she had expected to work for a non-profit after law school, commented that private practice grew on her: "I actually liked doing files, casework... In some ways it suited my personality more than doing the broad policy work. I liked working with clients and... understanding completely what my role would be." ${ }^{121}$ This lawyer successfully moved into private practice after the LLP folded.

Referral work was another problematic area. The LLP did contract work for other lawyers generally acting as juniors in cases or commissions of inquiry - and grew to work in areas including conveyancing work and work on aboriginal residential school compensation claims, among others. ${ }^{122}$ But in contrast to the support for PLS in the legal community, the LLP did not benefit from as many referrals as it had hoped for. ${ }^{123}$ While some types of referral work played a key role in the LLP staying afloat as long as it did, several interview participants indicated that the LLP might have been more successful if it had obtained more work from other lawyers. ${ }^{124}$ One partner described the importance of referral work as follows: "Our best work as far as I can tell, and what paid most of the rent for those years, was a senior lawyer who found him or herself on a big case and needed a junior and they would hire one of our lawyers to junior. And that was probably the most successful aspect." ${ }^{125}$ But aside from these types of cases, referral work seemed difficult to come by. Some attributed this to the relative inexperience of LLP lawyers, suggesting that they had not been practicing long enough for colleagues to know them and refer work. ${ }^{126}$

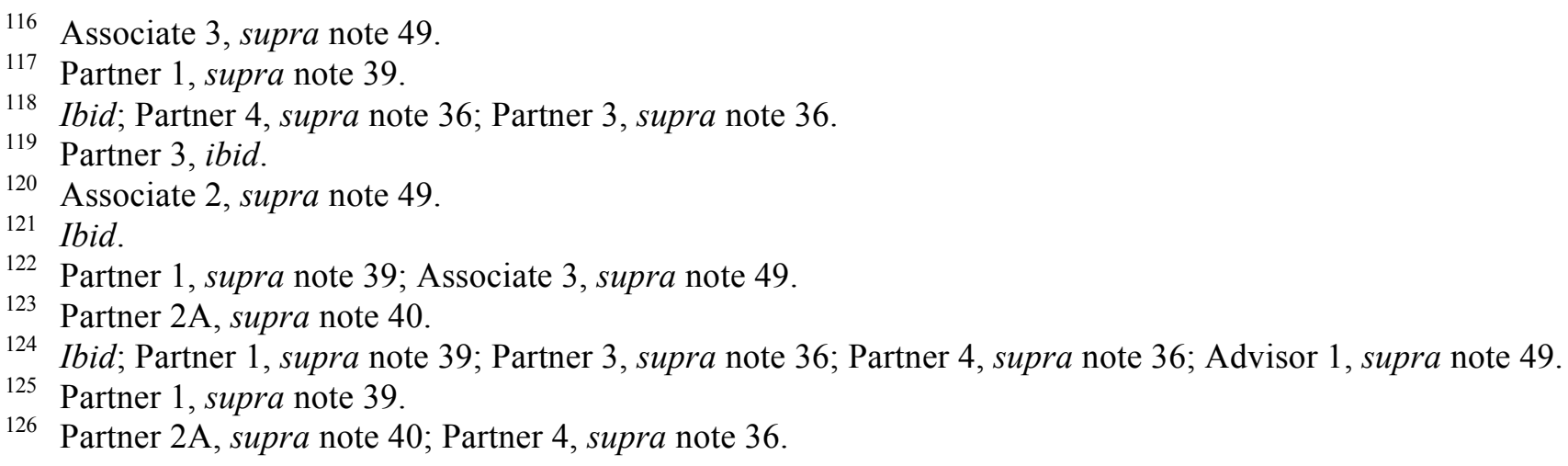


Where the LLP did bring in business, it often suffered from a poor mix of file types. Interview participants also suggested that the LLP took on too many contingency files. Contingency files are cases in which a lawyer receives payment only if the case is successful, usually a portion of damages awarded if a plaintiff is successful. Several interview participants commented on this. ${ }^{127}$ Moreover, the contingency files that the LLP took on were often complex, resource-intensive cases. ${ }^{128}$

Other interview participants commented that many lawyers took on files that were either pro bono or were significantly discounted. ${ }^{129}$ As one partner put it, "we attracted lawyers... who had a lot of trouble saying no for all the right reasons." 130 One of the partners suggested that trying to cater to both lowincome clients and more affluent clients was inherently problematic:

The group that wants their low cost legal services - they don't give a shit. You're all they can afford. If they could afford more, they would go somewhere else. So whatever, they don't care. And the ones who could afford more, they're choosing you because you're using - and they actually expect to pay more. So putting those things together was really tough."131

In addition to the lack of paying clients, difficulties in cultivating new clients, and poor file mix, some interview participants suggested that staffing problems also inhibited the LLP's development.

Eight of nine interview participants cited inadequate lawyer support as a significant problem. ${ }^{132}$ Two aspects of this problem emerged: first, there was insufficient practice area overlap among lawyers, and second, there was insufficient support staff for lawyers. ${ }^{133}$

Insufficient practice area overlap caused problems for the LLP in three ways. First, because most LLP lawyers were practicing in different areas, they could not discuss their work or professional challenges with colleagues. Second, insufficient overlap meant that lawyers could not cover for each other. Finally, important opportunities for collaboration and work cross-referral were missed. As one lawyer described it:

I think that was everyone's complaint, was that you had each person practicing their own thing, but nobody really around. At lunch, in the lunchroom, [Associate 2] could talk about immigration law, but it would have to be so cursory, because you never really got to the nitty-gritty of it. Yeah, that sucked a little bit. I mean you go to court and you're fighting a technical issue in litigation and you come back, and you can say you won, but

127 Ibid; Associate 2, supra note 49; Advisor 1, supra note 49; Partner 3, supra note 36.

128 Partner 1, supra note 39.

129 Staff 1, supra note 65; Associate 2, supra note 49; Partner 3, supra note 36.

130 Partner 3, ibid.

131 Partner 1, supra note 39.

132 Associate 3, supra note 49; Associate 2, supra note 49; Advisor 1, supra note 49; Staff 1, supra note 65; Partner 1, supra note 39; Partner 4, supra note 36; Partner 3, supra note 36; Partner 2A, supra note 40; Partner 2B, supra note 70 .

133 Advisor 1, supra note 49; Associate 3, supra note 49; Partner 3, supra note 36; Partner 1, supra note 39; Associate 2, supra note 49; Partner 4, supra note 36; Staff 1, supra note 65. 
you never really get that "and then I said this, and then I said that, and they said this." You'd never really get that feel. ${ }^{134}$

Indeed, this lack of practice-area support was described by one lawyer as one of the major reasons why she ultimately left the LLP: "I know that one of the reasons why wanted to leave is I wanted to be surrounded by other people doing the same work, because I wanted to be able to vent about issues and also to get advice." ${ }^{135}$ Since one partner cited the difficulty of marketing the LLP because of associates leaving, this problem may have contributed to the LLP's revenue-generating problems. ${ }^{136}$

The other aspect of the lack of support problem - the lack of support staff - was described as follows by one of the interview participants:

I couldn't do very many files at Pivot. I actually had not a big case load because administratively there was so little support that... You know, I'm writing the arguments and doing the research, but I'd also do the copies and binding and delivery. So I did everything to produce whatever it was. And so that takes... You can only reasonably do a certain number of cases, and so it was limited. ${ }^{137}$

Several interview participants commented that their practices were not efficient because they had to do everything themselves - including photocopying, binding, etc. - because there was insufficient support staff. $^{138}$

One of the partners, commenting on this problem, suggested that finding good legal support staff was a significant challenge for the LLP: "We worked hard over the years to get that in place with file management systems and all that sort of stuff, but at the end of the day we just didn't have a super genius legal administrator who was able to run a tight ship, and an assistant who could make your letters look perfect at a moment's notice and all that stuff.",139

The specialized nature of support staff may have been underestimated also. One partner indicated that practice-specific support staff is necessary:

Paradoxically, you have to have a sufficient level of expenses to generate the revenue for you to generate the efficiencies of scale. And we didn't have that. The support staff that we had could not be expected to help family lawyers, immigration lawyers, and personalinjury lawyers, and business lawyers all at the same time. ${ }^{140}$

And yet another lawyer stated that lack of support staff was a contributing factor to her decision to leave the LLP:

134 Associate 3, supra note 49.

135 Associate 2, supra note 49.

136 Partner 3, supra note 36.

137 Associate 2, supra note 49.

138 Staff 1, supra note 65; Ibid; Partner 3, supra note 36; Associate 3, supra note 49.

139 Partner 3, ibid.

140 Partner 2A, supra note 40. 
Having to do marketing, business development, practice support work... You're doing it all. And there is burnout. I think that was a big part of it. It burned me out. That was one of the big reasons why I was like "I can't do practice anymore."141

One final factor, noted by one of the partners, was that it was very difficult for young lawyers to set up a practice in the aftermath of the devastating cuts to legal aid that were made in British Columbia in $2002 .^{142}$ These cuts made it more difficult for the LLP to develop revenue streams that were available before the cuts.

The downfall of the LLP was unfortunate, not only because it meant a lost funding source for PLS and fewer legal services in the Downtown Eastside, but also because it seemed to signal that the LLP's new business model was not viable. But, as the next section illustrates, there are reasons to believe that the Pivot Legal LLP model could work.

\section{POTENTIAL LESSONS}

The story of Pivot Legal LLP could be read as a daunting cautionary tale for anyone hoping to start a legal services business dedicated to improving access to legal services. The LLP was built by four very intelligent and dedicated lawyers who had already created a successful legal advocacy not-for-profit organization. It received significant early access to credit from well-established funders in Vancouver who were committed to ensuring the long-term success of the organization. It was able to leverage the existing investments of a sibling organization for operating necessities, particularly office space and office equipment. Its principals were well-known within the Vancouver legal community and also to key funders. The organization won an award as a promising social enterprise, having been evaluated by some key business minds in Vancouver. It had excellent access to business planning resources, and made use of these resources on a number of occasions.

If an organization like this ultimately failed, what hope is there for others?

In fact, there is reason for considerable hope. First, every single interview participant was asked if they thought that Pivot Legal LLP, or a similar business, could work if a few key changes were made based on the LLP's experiences. All answered in the affirmative. Second, some of the apparent advantages enjoyed by the LLP may actually have been hindrances, and understanding this could help future law firms avoid the same mistakes.

The LLP's experience points to the importance of understanding that the ability to do legal work is different than the ability to attract new clients. Identifying this difference does not, however, lead to the conclusion that someone capable of one is incapable of the other - just that firms should pay attention to both aspects of lawyer development. It also highlights the importance of ensuring that lawyers understand and support the business model of a firm, recognizing that if the firm is unable to maintain

141 Associate 3, supra note 49.

142 Ibid. 
itself, it will be unable to provide legal services to those who need them. The experience of trying to make the LLP work was likely eye-opening for many of the lawyers involved. As one lawyer described it, the LLP experience forced a change in thinking about whether law is a business:

I used to hate it [when the partners at a previous firm] would say to me "[Associate 3], as much as it's law, it's a business." And I wanted to strangle them. I'd say "I went to law school to help the world." I would get so irritated. But then as I got going, I began to understand. But it wasn't until Pivot that all those words they had said to me became really clear to me. And then I was like "Oh gosh, I can never admit to them that they were right." But it is. At the end of the day, you still have bills to pay, you still have life to run, and the idealism of your twenties starts to die when you want to have things. ${ }^{143}$

Another insight from the LLP's experience is that business planning was not particularly helpful when it came to client development. Understanding how different types of clients decide whether to seek legal services, and if so, where to find legal services, would be very useful. One of the partners, who agreed that paying clients are often driven by a successful track record, suggested that the LLP's low fee model may have undermined its appeal to these clients:

I do think that people have an expectation that when they need legal services, they are going to want the big firm and the QC, and you know- "I have hired the biggest firm in Vancouver to take on my case because it's so important." They are not excited about "I have hired the community legal clinic that is marketed as providing affordable legal services to the east Vancouver neighbourhood." Nobody gets excited about that. And so people will pay more to get that for their case. So there's a flaw there. But there's also clients that would have - I still believe - that would have liked to have branded themselves as working through the LLP, but I think the mistake we made was leading with price as opposed to leading with the social benefits. And saying you would pay as much with us as you would with any other law firm, but understand that a portion of that's going to fund this other work that we do, and in fact you might even pay a premium for that, in order to work with us, because our first goal is to fund this other work [done by PLS]. Our mistake was to think that we could offer a discounted rate and that that would be enough. So I don't think the idea itself was flawed. ${ }^{144}$

Another partner made a similar point, suggesting that many clients use price as a proxy to determine a lawyer's skill. ${ }^{145}$ One of the LLP's advisors also adverted to the difficulty of assessing lawyer competence:

And honestly who in the heck could tell you really if the lawyer did a great job or not. You know that they were responsive. You know that the job got done. You know that the

${ }^{143}$ Ibid.

144 Partner 1, supra note 39.

${ }^{145}$ Partner 2B, supra note 70. 
bill didn't completely wreck your life. But you don't really know if somebody a little smarter... It's like a doctor. The doctor puts on a white coat and stethoscope and listens. How do you know? Why - because he's been in the office for 30 years. ${ }^{146}$

As legal scholar Gillian Hadfield has recently noted, the legal marketplace for individuals is poorly documented - meaning that it is difficult to understand how well or poorly this marketplace resembles a properly-functioning market. ${ }^{147}$ To the extent that some clients evaluate the quality of prospective lawyers by high hourly rates though, the LLP's reduced fee model may have actually undermined its appeal to potential paying clients.

Interview participants provided insightful opinions on how the LLP could have succeeded. In the words of one interview participant: "I think they needed to do what they originally did, which was keep it very limited. They needed to stick to their original practice areas, and make sure it was sustaining, and working, and making money, and thriving, before expanding into the other areas." 148 Another interview participant voiced similar sentiments:

...I think if it started with a group of people who had similar ideas about what they wanted for it, and then have a real plan as to how to implement that. So, not just "we need to get clients", but how? What kind of clients? How are we going to do this? I guess just more planning around what the work is. But I don't think that I ever thought it was impossible to work... It's just it has to operate, has to function as a firm. You have to have things in place that would allow you to do the legal work, which I don't think we ever were able to put in place. And that's... Some of that was just inexperience. People not knowing what is needed. ${ }^{149}$

One of the partners indicated that the LLP had provided valuable experience, and was optimistic that the firm could have been very successful if it had avoided some mistakes:

I think by the end we had figured it out. By the end we had a small number of lawyers, we had some firm, core clients who came regularly and were able to pay, and we had stopped taking crappy cases - we knew what a crappy case was and what a good case was, in terms of the ability to keep our doors open - but by then our debt servicing costs were so high that we were unable to stay above water. We had such incredible overhead that there was just no way to succeed. So that's why [another firm formed by two of the former LLP partners], I think, has been successful, because it took the learnings from the LLP. And I think that... I know that if we had a hundred thousand dollars, paid off all our

146 Ibid.

147 Gillian K Hadfield, "Higher Demand, Lower Supply? A Comparative Assessment of the Legal Resource Landscape for Ordinary Americans" (2010) 37 Fordham Urb LJ 129 at 151.

148 Associate 3, supra note 49.

149 Associate 2, supra note 49. 
debt and - just won it in a lottery let's say - that the firm would still be going, and would be very successful. ${ }^{150}$

These comments suggest that a law firm similar to the LLP could succeed. Perhaps more important than the comments, at least two of the former partners and one former associate were successful in creating two viable, stand-alone legal practices after the demise of the LLP. ${ }^{151}$ In each of these cases, the lawyers set up their new firms to either donate profits to PLS or to engage in significant amounts of pro bono or reduced-fee representation for clients who otherwise could not afford legal services. But in both cases, these new firms were much more disciplined than the LLP was initially.

In both cases, the new firms found reliable support staff, focussed on limited practice areas, and controlled their access to justice work by either charging commercially competitive rates and donating some profits to PLS or focussing on charging lower rates for members of the public who could not afford legal services. Not both. These lawyers learned lessons from the LLP experience.

These examples suggest that it is possible to create a successful law firm that focusses on social justice lawyering or improving access to legal services. These examples also suggest, however, that lawyers who create these firms will have to make strategic and perhaps difficult choices about how to be financially viable: for example, choosing to embrace low fee legal services instead of hoping to fund an organization like PLS, or vice-versa.

The legal profession and legal educators can do more to support this type of successful innovation. Luz Herrera makes this point about her own career path. After graduating from Harvard Law School, she "started [her] own practice without much context or the necessary knowledge or skills to develop a viable model." 152 As Herrera argues, "[t]he most consistent and largest employment sector for lawyers will continue to be solo practice. If the largest segment of our law students will eventually work for themselves, then law schools should provide direction about what it means to be a self-employed lawyer." 153 As a professor, she has now catalogued a number of emerging programs between law schools, bar organizations, and individuals to "help lawyers establish viable business models." 154 This may be a promising approach in Canada.

Gillian Hadfield, Richard Susskind and others have suggested that disruption of the current market for legal services is needed to improve the quality and affordability of legal services. ${ }^{155}$ Innovative legal practices, such as the LLP, are an example of one type of disruptive approach that could improve access. ${ }^{156}$

Lawyers in such firms may have to define "success" differently than lawyers in most law firms or businesses. Success for those lawyers will be measured by whether the firm improves access to legal services, rather than by the firm's profitability for its partners. By paying more modest salaries but

150 Partner 1, supra note 39.

151 Partner 2A, supra note 40; Partner 3, supra note 36; Associate 2, supra note 49.

152 Herrera, supra note 24 at 938.

153 Ibid at 891.

154 Ibid at 920.

155 Gillian K Hadfield, "Equipping the Garage Guys in Law" (2011) 70 Md L Rev 484; Richard Susskind, The End of Lawyers?: Rethinking the Nature of Legal Services (Oxford: Oxford University Press, 2010).

156 Herrera, supra note 24 at 894-896. 
creating an enviable work environment built around a mandate to improve access to legal services, law firms might lower their overhead costs, thereby allowing them to provide legal services at reduced rates. Other firms might choose a different balance, such as higher salaries but less focus on improving access. Creating law firms which explore how such business models could work - and ensuring that stories of those firms are told to law students and young lawyers - could be an important component of innovation in delivering legal services to improve access to justice.

The LLP tacitly worked on the premise that lawyers would be willing to work for a lower than market salary, provided that they could do more meaningful work. As one of the partners explained:

One of the key ideas behind the employment - because we were all in that scenario - was that lawyers would give up some portion of their salary in order to do more meaningful work. And so sure you would only be making $\$ 60,000$. But you would be working on cases that were going to the Supreme Court of Canada on drug user rights like Insite, or whatever. So that would make up for whatever you were giving up in terms of having a bigger place, or whatever... ${ }^{157}$

This approach appears to have been successful. As one interview participant, who had moved on to private practice, described the role of money as a motivator:

Even here, doing private practice, I still don't earn a high salary. ... So that's not a motivator. The motivation is I really think it's important work that has to be done. And I generally like my clients, and I think I'm good at it, so that motivates me. And because I think that I can contribute. Sometimes it can be difficult. I still feel lucky. In my work there's always something changing. There is always something new. I get to meet people that I otherwise don't think I would ever get to know, just the way our society is, I don't think I would ever get to know them. So it's interesting to just know about things that I wouldn't otherwise. So I'm always learning in that sense." 158

Several interview participants noted that many law firms do work to promote socially beneficial causes such as access to justice, but that relatively few of these firms identify this aspect publically or prominently. ${ }^{159}$ Engaging in a direct conversation with lawyers about not only the need to improve access to civil legal services, but how individual lawyers can help improve access, is an important way to encourage innovation in delivering legal services.

Ronit Dinovitzer and Bryant Garth have noted that control over decision making and supportive mentoring are factors that have been found to increase lawyers' work satisfaction. ${ }^{160}$ Echoing the importance of control over decision making, one of the LLP partners noted the effect of autonomy at the LLP:

157 Partner 1, supra note 39.

158 Ibid.

159 Partner 3, supra note 36; Associate 2, supra note 49.

160 Ronit Dinovitzer \& Bryant Garth, "Getting at the Cause of Dissatisfaction" (2010) 10:4 Compensation \& Benefits for Law Offices 1 at 7-8. 
People were very autonomous, which created its own problems, but it does also have its own advantages. You don't have someone standing over you all the time telling you how to practice, which nobody really likes. I'm sure that some people do, but they must be in the minority. ${ }^{161}$

All of this suggests that the LLP model is viable, with some modifications. A law firm focussed on developing a collegial workplace, doing socially-meaningful work to improve access to legal services, providing lawyers with some work autonomy and time flexibility, and providing good mentorship opportunities to young lawyers might be able to attract and retain lawyers without promising the inflated salaries that are taken to be the norm in many large law firms.

\section{CONCLUSION}

In this paper, I have suggested that a law firm that is designed not around maximizing profits for partners, but around providing legal services to citizens, might hold promise alongside other projects to improve access.

The research in this case study does not offer definitive proof that innovative law firms which address unmet legal need will succeed, but the example of Pivot Legal LLP is suggestive. Unmet civil legal need is pervasive across Canada. Lawyers - and young lawyers in particular - appear ready for innovative approaches to the practice of law.

Pivot Legal LLP was a worthwhile venture. Although the firm lasted only four years, those involved remain optimistic about the long-term viability of a similarly-structured firm. The Pivot Legal LLP experience provided valuable lessons to the staff and lawyers involved about how to run a successful law firm. In this article, I have tried to uncover some of those key lessons and share them with a wide audience. Hopefully, some will take these lessons and use them to create new and sustainable law firms dedicated to improving access to legal services.

Though Pivot Legal LLP is no longer in operation, it did not fail in demonstrating that there are innovative and exciting ways to practice law. In the words of one advisor: "Something not working is not failure. Failure of imagination, failure of values, failure of integrity - those are failure. But failure of an innovative, bold business idea?" ${ }^{162}$ This is a call for lawyers to engage their imaginations.

161 Partner 2B, supra note 70.

162 Advisor 2, supra note 83. 